\title{
5 IS IT REALLY A PLACENAME?
}

\author{
Luise Hercus
}

There are few topics as challenging as the study of Australian placenames. Their formation varies from region to region, they may be analysable or not, they may refer to the actions of Ancestors, they may be descriptive, or 'indirectly' descriptive: an Ancestor is said to have noticed some particular feature and named the place accordingly. That feature may or may not be permanent. Placenames may be single morphemes or consist of a whole sentence, they may show archaic features. In any case they are unpredictable: we can never guess what a place was called. We can also never be sure we are right about a placename unless there is clear evidence stemming from people who have traditional information on the topic. In the absence of such evidence we have to admit we are only guessing. While, for instance, within the bounds of grammatical rules one can know with reasonable surety how to make certain verb forms, with placenames there are no such bounds; the only limitation is the extent of human imagination. That is why, in those cases where there is clear evidence, they can tell us so much about how people thought about their country.

This paper is intended to illustrate this from two specific angles, the use of generic terms as names, and the use of apparently 'silly' names.'

\section{GENERIC TERMS ${ }^{2}$}

If we look at general dictionaries of the past, rather than just placenames, there are many instances of the use of general terms where one might have expected a specific term. This happens sometimes even in the most brilliant and valuable documents from the past. Thus Stone's important vocabulary of Wembawemba (1911) has the following entries:

In general, Aboriginal words transcribed from modern recordings are in bold typeface; Aboriginal words quoted in early literature are in italic typeset and Aboriginal words transcribed from modern recordings and used as a placename are in italics, bold typeface.

2 Italics have been used for words that have been recorded in the recent past on tape, inverted commas are used for data from written records.

L. Hercus, F. Hodges and J. Simpson, eds, The Land is a Map: placenames of Indigenous origin in Australia, 63-72. Canberra: Pandanus Books in association with Pacific Linguistics, 2002.

(c) Luise Hercus 
fire sticks (saw) wannup

when it is clear from all the other evidence of Wembawemba that wanap is simply the general word for 'fire, firewood', and does not necessarily have the specific meaning of 'fire sticks'.

net peg

gunneneuk

when it is clear that kani is the general term for any large stick or pole, and kani-ny-uk, i.e. kani followed by a linking consonant and the third person possessive marker, means simply 'his/her/its pole' and has no direct association with a net.

necklace (crayfish claw) mannunyeuk

when manya is the general term for 'hand', and manya-ny-uk, that is manya followed by a linking consonant and the third person possessive marker, means simply 'his/her/its hand' and has no association as such with a crayfish and still less with a necklace.

In the case of placenames the situation is a little different: a general term may in fact $\mathrm{BE}$ the actual specific term. There are just a few obvious examples of this:

For the Paakantyi people of the Darling River, the Darling river was Paaka 'The River', the only one that mattered: it had no other name.

The most spectacular example is that of the Diamantina/Warburton. Anyone who has flown over the southern Simpson Desert will have seen the deep channel of this river as it winds towards Lake Eyre. North of Clifton Hills in the far north-east of South Australia a smaller channel comes out of the Diamantina westwards, twists and bends and ultimately rejoins the main channel before it reaches Lake Eyre. For hundreds of miles to the north there are only sandhills and no sign of any river or creek, nothing, until one reaches the lowest flood-outs of the Hale and Plenty rivers. So for the Simpson Desert Wangkangurru people the Diamantina/Warburton was THE Creek, Karla. It had no other name. The smaller ana-branch that wound out of it was THE Little Creek, Karla-kupa, the Kallakoopah. In both these cases a general term doubled as a specific term. An interesting point is that in the case of the Kallakoopah this analysis is no longer quite true: the adjective kupa 'small' is the standard term for 'small' in the closely related Arabana language, but Wangkangurru people say nyara for 'small'. As this name and several fixed locutions show, Wangkangurru people must have said kupa once upon a time. So the name Kallakoopah represents an archaism and also shows how a general and completely analysable name can be on the way to becoming at least partly unanalysable and therefore uncontroversially a name. 


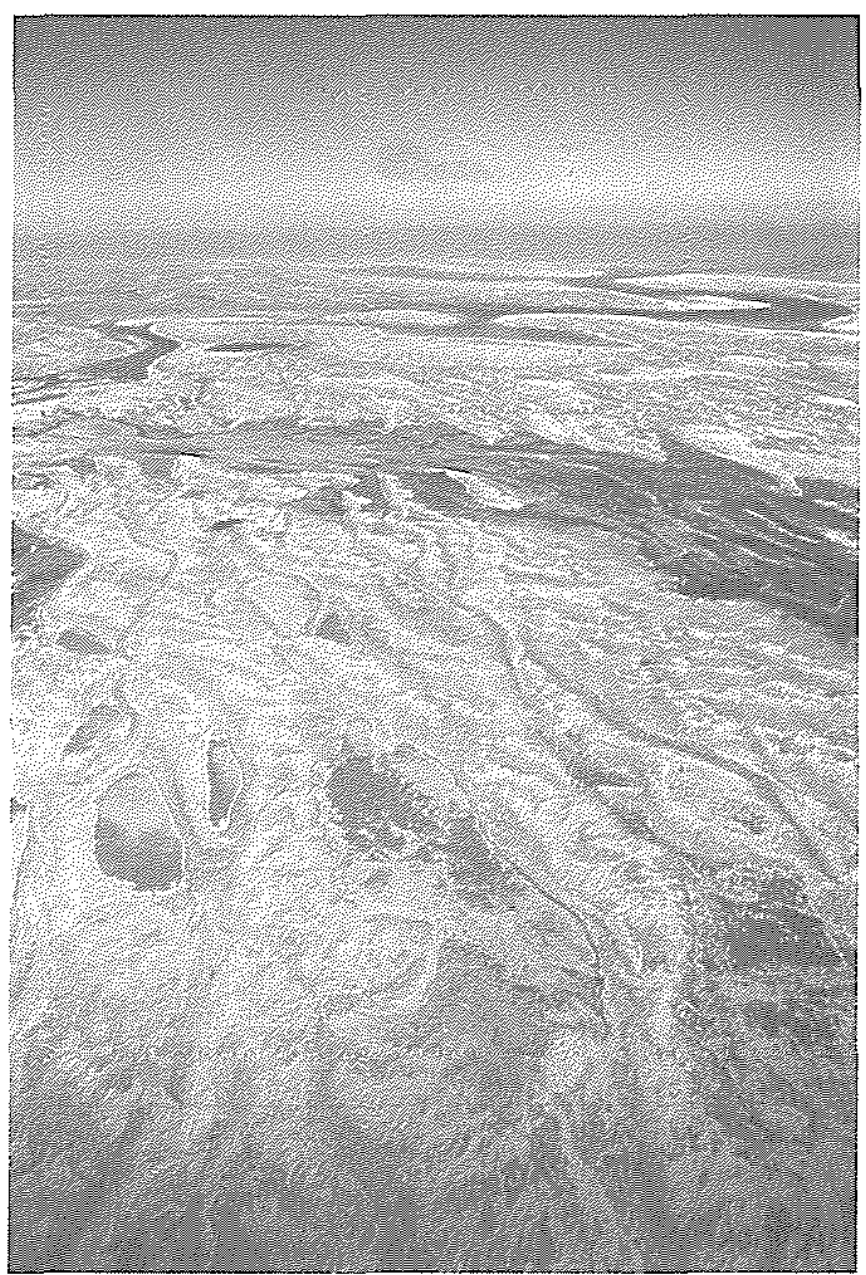

Figure 1:'THE Creek', Karla, winding through the southern Simpson Desert. Photo: L. Hercus

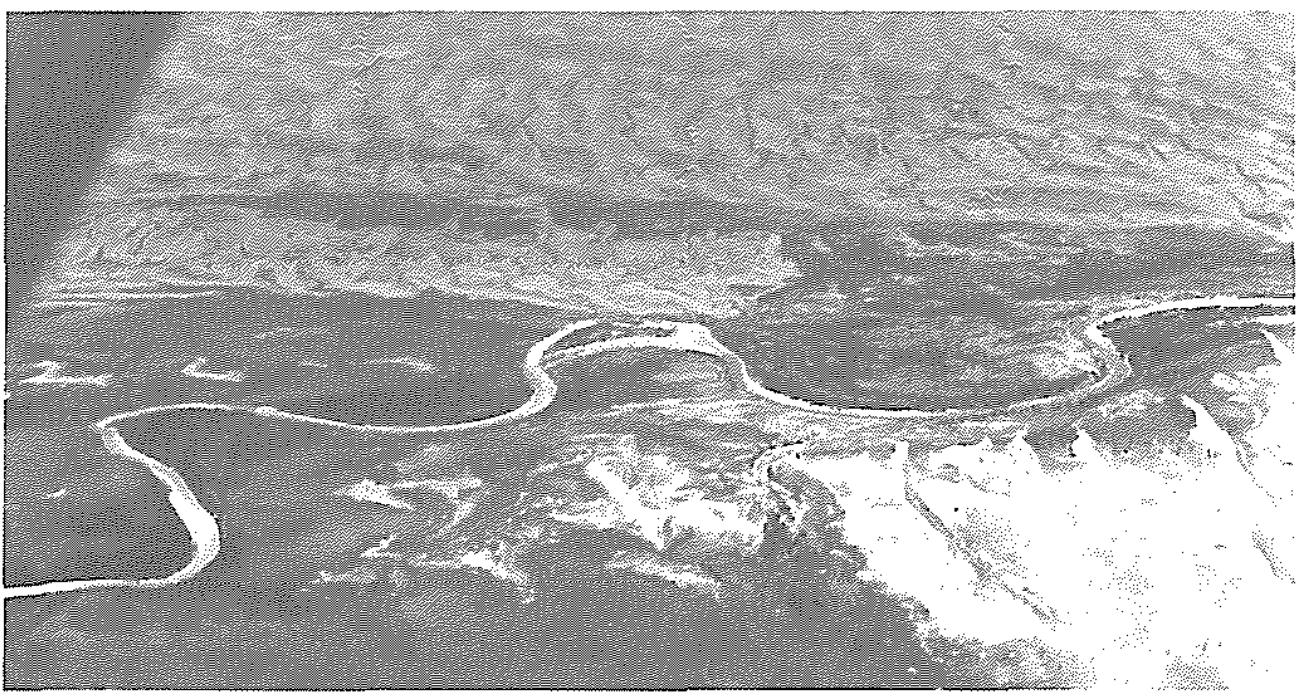

Figure 2:'THE Little Creek', the Kallakoopah, winding through the Simpson Desert. Photo: L. Hercus 


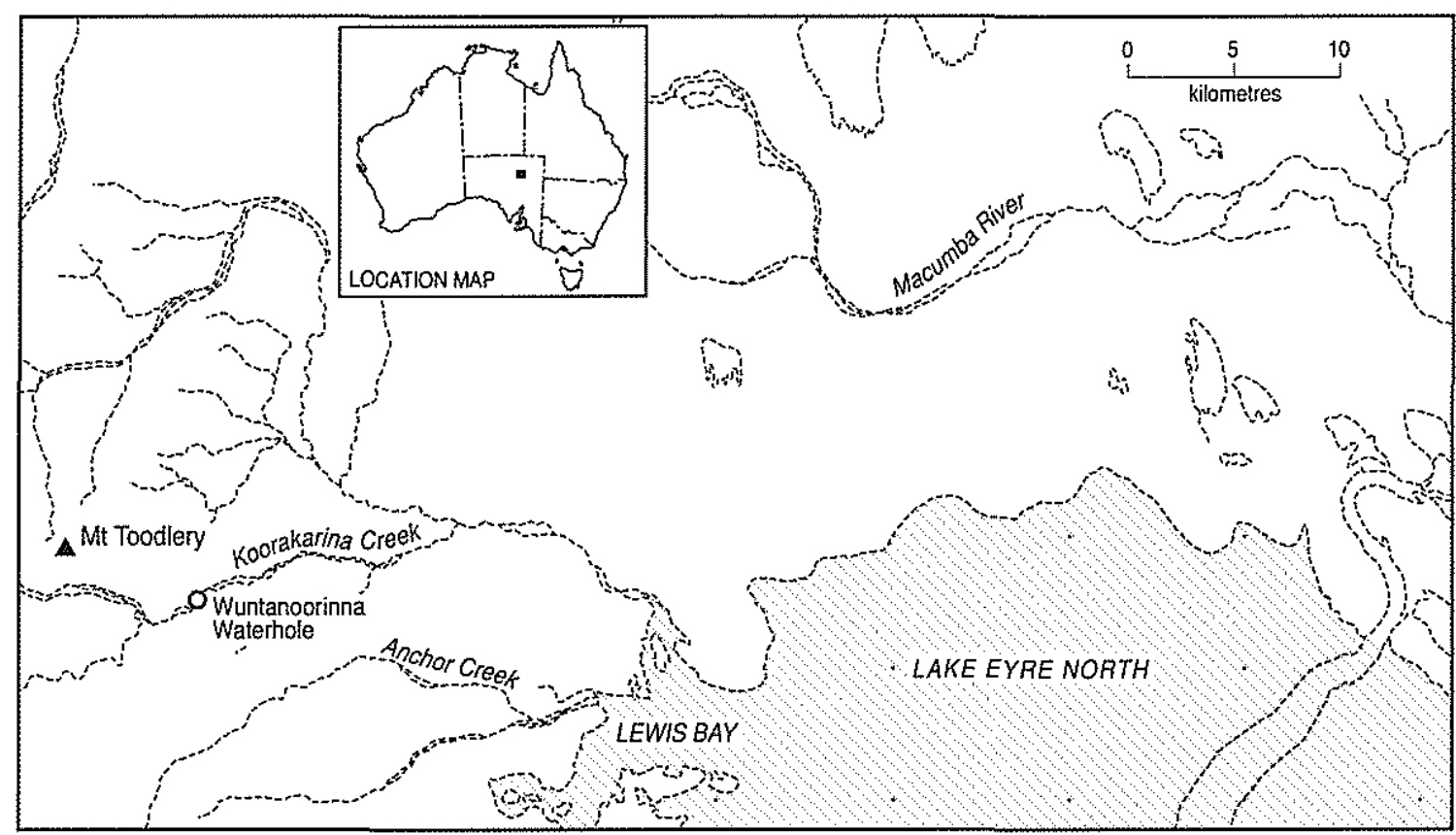

Map 1: Mount Toodlery and surrounding area

There can be other cases where a general term is used because there is no specific term: the feature in question may seem to Europeans as meriting a specific name, but not in Aboriginal eyes. Thus about 15 kilometres to the west of the north-westernmost corner of Lake Eyre the maps show Mount Toodlery. This is not a prominent peak, it is nothing but an elevated rocky tableland, and the highest point of it has a trig. It is the sort of place where it is absolutely impossible to drive, and I would say even to walk, just an elevated vast expanse of rocks and boulders. So presumably the Arabana people, whom the surveyors must have asked about it, called it thurliri 'rough stony country'. There was a name for an elevated part of the tableland that was closest to the Wuntanoorina waterhole, it was Unthu-nyurinha kadnha: it was where the Initiands were kept in the Two Men History associated with Wuntanoorina Unthu-nyurinha waterhole, and the name refers to circumcision. The part of the elevated tableland with the trig, however, did not have a specific name. So it was not surprising that some years ago, when I started talking about Mount Toodlery, nobody seemed to know where I meant. When we actually got into the vicinity of this place the Arabana speaker Arthur McLean said: 'that is thurliri all right, rough country' - i.e. thurliri was a term that could be used for any such area, and there are plenty such in Arabana country. ${ }^{4}$ In these more traditional regions, this is a rare instance of such a word ending up as a specific placename. There seem to be altogether relatively few instances of general terms used as specific, both of

3 The Arabana word thurliri 'rough tableland country' has an etymological connection with the well-known Arabana word thurla 'sharp stone', which has become part of archaeological vocabulary in English as 'tula adze'.

4 To illustrate the unpredictability of placenames: Mount Robinson to the west of Mount Toodlery is an equally inhospitable big plateau and traditionally it was called Yaltya watinha 'track of the waterhole frogs', because the by then desperate Ancestral Waterhole Frogs travelled all the way up there in their search for the swamp by the Macumba where they ultimately came to rest. 
the Karla type where the general term doubles as a specific name, and the Thurliri type where there is no specific name.

In Victoria, ${ }^{5}$ where there was considerable language loss at a much earlier date, lists of placenames, just like the ordinary dictionaries, contain a number of what appear to be general terms identified as referring to a specific item/location. In the case of dictionaries, as in the examples from the work by Stone, quoted above, this is usually because the questioners expected there to be a special term when there was none, which involves to some extent a lack of communication. In the case of locations the question arises: are they really placenames or just general terms that have been used, perhaps again through lack of communication, in this case usually between a surveyor and Aboriginal people. A surveyor may have pointed at a creek and asked 'what do you call this?', only to get the answer 'the creek', and he may have then carefully noted and reported the term as a placename, when the specific name of the creek may have been quite different. Typical Victorian examples are:

From yaluk, 'creek' in Central Victoria and some western Victorian languages:

Yallock Creek former name of the location of Koo Wee Rup, south-east of Melbourne

Yallock Creek creek that flows into Western Port Bay (near Koo Wee Rup)

Moyne River Port Fairy River, originally known as Yalloak, 'a shallow swampy stream' (Lane 1869 in Smyth 1876 vol.2:186)

From pirr 'creek' in Wembawemba, Perepaperepa and Djadjawurrung:

Barr Creek is the name of part of the Gunbower Creek, close to the Murray River. The name indeed corresponds to pirr: because of the fact that when an $-\mathbf{r}$ - sound follows the $\mathbf{i}$, there was some lowering of the vowel. The spelling of the placename presumably represents this; other early spellings are bur, ba. There is also a Piccaninny Barr Creek, known in 1870 as Little Bar Creek (Contract Surveyor to Surveyor-General, 8/8/1870). ${ }^{6}$

From brim, 'spring':

Brim is a place on the Henty Highway north of Warracknabeal. The name was originally the name of a station, and it was recorded by the surveyor Chauncey and translated as 'a spring or well with water': Smyth (1876 vol.2:205). The name probably derives from the station and may not be the result of immediate communication by a surveyor with Aboriginal people.

Brim Springs is just south of Horsham, and there is also mention of a name Brim Brim for the same area. This reduplicated form is also quoted by Thornly in Smyth (1876 vol.2:60) with the meaning 'spring'.

From buluk, 'lake, swamp' in Djadjawurrung, Djabwurrung and southern Central Victoria: Buloke. It is not surprising that this general term should be used for Lake Buloke near Donald in Central Victoria. It is a particularly important large lake, prolific in wildlife once upon a time, and notorious in more recent times as the place where, at dawn on the opening day of the season, shooters sometimes shot each other instead of the ducks. It can, however, be

\footnotetext{
5 I am deeply indebted to lan Clark for permission to use his database on Victorian placenames.

6 Information courtesy of Ian Clark.
} 
shown from data of the 1870 s that there was also a specific term Banyenong for this lake alongside the general term 'THE lake'.

The same word is represented by the name of Lake Bolac, which is just off the Glenelg Highway, a little more than halfway between Ballarat and Hamilton. It is not as big as Lake Buloke, but is the biggest lake in the area, and must have constituted an important resource for local people. It too might well therefore have been THE Lake.

Bulluc-bulluc. This name was noted in Robinson's Journal (Robinson journal, $19 \mathrm{March}$ 1840, see Clark 1998) for an area which is now part of Melbourne. The reduplication indicates that this may mean 'a lot of swamps', 'a swampy area'.

From words meaning 'head', 'hill', i.e. purk, purp, panyul, and kowa, 'high mountain': Bork-bork. The use of the word for 'head' to mean 'hill' is widespread. The word purk for 'head' is given for Djabwurrung by Dawson (1881:xix puurk, 'head') and the general term 'Bork-bork', 'heads, mountains', is attested to refer to a forest hill north of Raglan, not far north of Beaufort (Porteous in Smyth 1876 vol.2:179). This term was also used to refer to the Pyrenees 'Range at head of Waterloo' (Surveyor-General's list of names in Smyth 1876 vol.2:194). The Pyrenees were The Hills in this area, and the use of the term for just one small part, the hill north of Raglan, may be an error.

Panyul is a mainly Central Victorian word for 'hill'. It occurs as 'Banyule', the name of a hill in the Heidelberg area of Melbourne and this has survived in the name 'Banyule Flats Reserve'.

Cowa, according to surveyors' returns, was the original name for Mount Arapiles. As this stands out all alone, away from the Grampians, it is understandable that it should be called The Mountain. The same name is attributed to the whole of the Grampians Range by Wilson (Smyth 1876:178).

From words meaning 'sand', kolak, kurak, and maloga (Yota-yota):

There are several placenames that simply represent the word for 'sand' in various Victorian languages. The northernmost is Koorakee in New South Wales some 18 kilometres north-east of Robinvale. This represents Mathi-mathi / Letyi-Letyi kuraki 'sand', and it corresponds to kurak in the other Kulin languages. A form kulak is found in Dhauhurtwurrung and the Colac language, hence the name of the township of Colac.

Korrac 'sand' is the name of a parish by the Avoca River, south-east of St Arnaud in Victoria (Tully 1997:88).

Cor.rac.cor.rac, i.e. Kurak-kurak, 'a lot of sand' is reported to be the name of a creek east of the Woardy Yalloak Creek: Robinson journal, 12 August 1841 (I. Clark:1998).

Torn. This word is given in Dawson's own vocabulary as 'hummocks of sand' for 'Peek whurrung', the language of the Warrnambool-Port Fairy people, and this would undoubtedly be the meaning of the placename. It is, according to Dawson, a place just west of Warrnambool which does not have a special European name.

Maloga. The name of the old mission station by the Murray meant 'sand' in Yota-yota.

There are general terms for other natural features which also occur as placenames, examples are:

Pyalong, between Kilmore and Heathcote in Central Victoria, simply means 'red gum trees'. The reduplicated form of the same word, Bael-Bael 'a lot of gum trees', is the name of a lake near Kerang. Piel, an old name of a salt lake in the Camperdown area (Scott in Smyth 1876:183), represents the same word. 
Terrick Terrick near Pyramid Hill gets its name from Wembawemba/Perepaperepa terik 'gravel'; Drik Drik 'limestone' in far south-west Victoria, just north of the Lower Glenelg National Park, is probably a cognate word.

The uncertainty of placenames is truly evident here: all these placenames may well have been just general terms noted as names by mistake. We can make some tentative suggestions from the nature of some of the places. Of the names listed above Torn is the one most likely to be of the thurliri type, that is, a place that did not have a specific name. It is probable that Dawson's informants had been asked 'what do you call this place?' and they came up with a general rather than a specific answer 'hummocks of sand'.

\section{2 'INTERMEDIATE' NAMES}

In Arabana country on the western side of Lake Eyre there are many creeks rising from the rough ranges, and some longer rivers that traverse some distance before reaching Lake Eyre. There is no unique creek, unlike the Simpson Desert situation, and all the major creeks have Arabana proper names. These sometimes do not follow the same pattern as the English names: thus on modern maps the Pootneura Creek joins the Lora Creek and this then joins the Arkaringa Creek. In Arabana nomenclature the Pootneura Creek is the dominant creek all the way and the other creeks join it. Apart from the proper names, people sometimes referred to creeks by what might be regarded as a semi-generic or 'intermediate' term. Creeks can differ from each other by the type of trees that grow there, and so people may refer to a creek as 'red gum creek', apira-karla, usually the largest; 'box creek', pitha-karla, usually also a main creck with permanent or semi-permanent waterholes; 'gidgee creek', urinyingka-karla, 'red mulga creek' amuna-karla (only in the far north), or 'tea tree creek' ityara karla (only in the far south). These terms are mainly used in circumstances where the speaker thinks it is quite clear to the listener which creek is meant and he does not need to give the actual specific name. Similarly swamps are sometimes referred to by the Arabana equivalent of 'box-swamp' or 'canegrass swamp', when there is also a quite specific name. These new descriptive names are as it were familiar terms, the speaker visualises the specific place and does not need to give the specific proper name. I am aware of only one such name that has come down to us superseding a specific placename. ' These 'intermediate names' are however represented in English translations, even when there is a well-known Aboriginal proper name, hence Box Creek (for Ulyurla karla 'Old Woman Creek'), and the former Box Creek siding on the old Ghan line north from Anna Creek, 'Red Mulga Creek' south of Dalhousie, and in Kuyani country, well to the south, the politically notorious 'Canegrass Swamp' (for Piya-piyanha) in the neighbourhood of Olympic Dam.

There are some descriptive placenames in Victoria which could once upon a time have been such intermediate terms, for example, Wycheproof, that is, Wityi-purp 'basket-grass hill'; Narragil Creek near Maryborough from ngari-wil 'having she-oaks'; Dharugill, a spring in the Heytesbury area south of Camperdown, 'a spring etc., a plant' according to Scott in Brough Smyth (1876:184) probably from dharuk-wil, 'having dharuk plants, plants with edible roots'; Wood Wood, a township near the Murray River down from Swan Hill from wurd-wurd, 'bulrushes'. The names in question may simply be descriptive specific names, but they may also be 'intermediate' type names.

This is Ityara karla 'Tea Tree Creek', which is used by Arabana people for Stuart Creek South, in Kuyani country superseding an unknown previous Kuyani name. 


\section{3 'SILLY' NAMES}

In placenames it is easy to find some that look at first sight like quite silly mistakes arising from a lack of communication:

Thus there is a small township south of St Arnaud in Victoria named Winjallok. The surveyor Philip Chauncy recorded this name (cf. R. Brough Smyth 1876 vol. 2:211). He also recorded that it meant 'where is it?' This interpretation is indeed correct. The place is in Djadjawurrung country and this language is very close to the neighbouring Wembawemba. The Wembawemba word wintya means 'where' (Hercus 1992). Grammatical markers can be added to this, with a linking consonant -I-. Hence, with the addition of the third person marker -uk we have wintyaluk 'where is he/she/it?' It looks like an obvious example of lack of communication, and as Tully (1997:92) suggests in his dictionary of Djadjawurrung: 'It appears that the informant was not sure where Chauncy meant'. Chauncy however recorded the translation: would he have recorded the sentence if he had doubts about it representing a placename?

Mount Beckworth in Central Victoria, a few kilometres west of Clunes, was once called Nananook. This name was recorded by A. Porteous in R. Brough Smyth (1876 vol. 2:178), and he gives the translation 'behind'. This name probably represents a word similar if not identical to Wembawemba nyaninyuk 'the back of his/her neck' (nyani 'back of neck', -nylinking consonant for the third person after nouns ending in vowels, and -uk, third person marker). The word for 'back of neck' is used in many general contexts where the term 'back' would be used in English, hence the translation 'behind' is not surprising. Tully (1997:89) suggests 'this appears to be an example of confusion between Porteous and his informant, as nananook means literally behind him'. But why would Porteous, like Chauncy, knowing what the word meant, record this as a placename?

Another such placename is 'Nawalah', 'what is it?', Wilson in Smyth (1876 vol. 2:178). It is the name of a place to the north-west of Stawell. This name can be analysed as nya wala, 'what is it?' The interrogative base for inanimates in Werkaia and other W. Kulin languages is nya: in Werkaia the full form for 'what' is the reduplicated nya-nya, but in Djabwurrung the simple nya was used: the placename implies that this was also the case in Jardwadjali. The pronominal base in both Werkaia and Wembawemba is wal, hence wala-ny-uk (with the addition of the third person possessive marker) means 'he, she, it'. The third person marker was not necessarily required, one could therefore say nya wala, 'what is it?' This could well have been an utterance of a perplexed Elder, but was it? Why would a surveyor, knowing what the name really meant, list it as a placename?

Wategat is the name of a place just west of the Grampians: it is mentioned by Thornly in Smyth (1876 vol. 2:62) as Wateegat with the translation 'come, come here'. The verb wardameans 'to come' in neighbouring Werkaia. The second person plural imperative of an intransitive verb is not attested for Werkaia, it was -iaty in Wembawemba (transitive -akaty). The Werkaia ending might well have been -ikaty, with the $\mathbf{k}$ preserved as in the transitive. Wategat is in Yardwadjali country and so the name of the place actually gives us grammatical information about the second person plural imperative in Jardwadjali and probably Werkaia. In any case the name means 'You (pl) come!' Could it have been that an Elder wanted to draw the attention of a surveying party to some feature, and the word was noted as a name by mistake?

There are similar types of placenames in an area where traditions have remained alive longer, and this can throw some light on the situation. Just to give one example: in the far north-east of South Australia, south-east of Birdsville and about 25 kilometres from the 
Queensland border, is a large, usually dry, lake called Etamunbanie. This represents ita 'that way' manpa 'go' + ni placename marker. The general meaning is 'you go that way (while I go this way)' in Yawarawarrka ${ }^{8}$ (Breen MS). It is very tempting to think that a Yawarawarrka man, accompanying the surveyor to this rather desolate and windswept spot, got tired of going around with him and used this opportunity of saying so, more or less telling him to get lost, without the surveyor understanding what was going on and noting it down carefully as a placename. In this case, however, there are still people who know the derivation: the actual explanation of the name is quite different.

This lake, Etamunbanie Lake of the maps, is set in the middle of a wide plain: it belonged to the Mindiri Emu tradition, one of the most important traditions of the Lake Eyre Basin. An area near Etamunbanie Lake was one of the three main sites for the Mindiri ceremony for which people came from far afield. The main Mindiri dancing ground was by a tree on the edge of the lake. The myth relates how, after they had completed a ceremony there, two groups of emus split up and one said to the other ita manpa 'you go that way (while we go this way)'. There is a verse which contains these exact words, followed by some rude departing jibes at this second lot of emus. This is how the place got its name according to the traditions of Yawarawarrka people. ${ }^{9}$

It is therefore quite possible that in the Victorian instances there were similar explanations: an Ancestor, in circumstances which we do not know, may have said wintyaluk 'where is it?' or nyaninyuk 'behind him' or nya wala, 'what's that', or wateegat, 'come here!' Porteous and Chauncy and other surveyors may not have made mistakes at all. As in the case of the possible general terms given as specific placenames, we cannot know for sure, but it could well be that these names, as in the example of Lake Etamunbanie, are not due to lack of communication, but reflect the utterances of Ancestors to whom these places held a special significance.

We do not know the answers to the suggestions raised, but the study of Australian placenames is in its infancy. In Victoria, in particular, work in progress by young scholars on some of the earliest maps and on early manuscript material means that we may ultimately recapture at least some of the Aboriginal vision of the landscape that is provided by placenames.

\section{REFERENCES}

Breen, J.G., n.d., A Yandruwantha dictionary. MS.

Clark, I.D., 1998, The Journals of George Augustus Robinson, Chief Protector Port Phillip Aboriginal Protectorate. Melbourne: Heritage Matters.

Dawson, James, 1881, Australian Aborigines. Melbourne: George Robertson. Facsimile edition 1981. Canberra: Australian Institute of Aboriginal Studies.

Hercus, L.A., 1992, Wembawemba Dictionary. Canberra: the author.

\footnotetext{
The main source of information on the Yawarawarka comes from J.G. Breen's work on the neighbouring and closely related Yandruwantha language (Breen:MS).

9 The information actually came from a Wangkangurru speaker who was familiar with the area.
} 
Smyth, R. Brough, 1876, The Aborigines of Victoria and Other Parts of Australia and Tasmania, vol. 2. Melbourne: Government Printer.

Stone, A.C., 1911, The Aborigines of Lake Boga. Royal Society of Victoria Proceedings 23:433-468.

Tully, J., 1997, Djadjawurrung Language of Central Victoria, including Place Names. Maryborough: the author. 